\title{
Separation strategies for invertebrate dormant stages contained in sediment
}

\author{
Elizabeta Briski ${ }^{1, *}$, Sarah A. Bailey ${ }^{1}$, Hugh J. MacIsaac ${ }^{2}$ \\ ${ }^{1}$ Great Lakes Laboratory for Fisheries and Aquatic Sciences, Fisheries and Oceans Canada, 867 Lakeshore Road, Burlington, \\ Ontario L7R 4A6, Canada \\ ${ }^{2}$ Great Lakes Institute for Environmental Research, University of Windsor, Windsor, Ontario N9B 3P4, Canada
}

\begin{abstract}
To accurately assess community composition of invertebrates, both active and dormant life stages should be considered. Dormant stages are typically produced as a strategy to overcome inhospitable environmental conditions and can also facilitate species dispersal. While they often sink and accumulate in sediment of natural habitats forming 'egg banks,' dormant stages are also found in the sediments accumulated in ships' ballast tanks. Recent studies have used 2 different methods to separate dormant stages from ballast sediment to assess invasion risk associated with ballast tanks: the colloidal silica sol Ludox HS 40 and sugar flotation (i.e. the Onbé-Marcus method). It has been assumed that the Ludox HS 40 method is most effective for separation but reduces dormant stage viability whereas sugar flotation has lower separation efficacy but higher resulting viability. We conducted a comparative assessment of the 2 methods by separating dormant stages from 160 ballast sediments and examining resulting abundance counts, hatching results, DNA extractions and PCR amplifications. We found no difference in the results between the methods. The financial cost of sugar flotation is lower than that of Ludox HS 40, and costs can be further reduced by using only 1 method instead of both due to lower labour costs, particularly for a large number of samples.
\end{abstract}

KEY WORDS: Colloidal silica sol Ludox HS 40 . Method comparison · Onbé-Marcus method · Sugar flotation

\section{INTRODUCTION}

Invertebrates and their dormant stages are an essential component of most freshwater and marine ecosystems (Cáceres 1997). As the active invertebrate community has a very variable distribution, both in time and space (Arnott et al. 1999, Folt \& Burns 1999),

*Email: elizabeta.briski@dfo-mpo.gc.ca

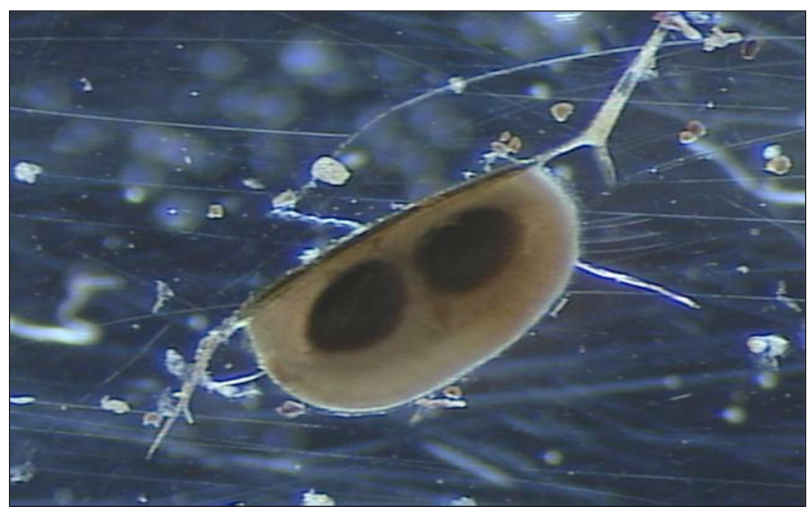

Daphnia magna dormant stage with remnants of sediment

Photo: Elizabeta Briski

reliable assessment of community diversity consequently requires repeated sampling across multiple locations for a prolonged period of time. Various invertebrate taxa produce dormant stages such as dormant eggs (also called diapausing eggs or resting eggs), cysts, or statoblasts that often sink and accumulate in sediments, forming 'egg banks' (Brendonck \& De Meester 2003). Dormant stages provide a mechanism for invertebrates to endure inhospitable environments and to undertake natural long-distance dispersal (Cáceres 1997). Sediment egg banks integrate spatial, seasonal and annual variation in the abundance and distribution of invertebrates (Brendonck \& De Meester 2003, Jeppesen et al. 2003). To accurately assess community composition for purposes of taxonomy, ecological biogeography, paleolimnology, nature conservation, and evolutionary, community, population and invasion ecology, both active and dormant stages of taxa should be considered (Brendonck \& De Meester 2003).

(C) The authors 2013. Open Access under Creative Commons by Attribution Licence. Use, distribution and reproduction are unrestricted. Authors and original publication must be credited. 
Aquatic invertebrates and their dormant stages are frequently carried in ballast water and sediment of commercial ships. The ability to determine invasion risk based on identification, abundance and viability of transported taxa can be extremely problematic (Bailey et al. 2003, 2005, Duggan et al. 2005, 2006, Briski et al. 2010, 2011a,b,c). Recent studies assessing invasion risk have used 2 different methods, the colloidal silica sol Ludox HS 40 and sugar flotation (i.e. the OnbéMarcus method; Onbé 1978, Marcus 1990), for separation of dormant stages from sediment (Bailey et al. 2003, Duggan et al. 2006, Briski et al. 2010, 2011a); the assumptions were that colloidal silica sol Ludox HS 40 separates biota and dormant stages from sediment more effectively than does sugar flotation, providing more accurate abundance estimates (Persmark et al. 1992, Burgess 2001), but reduces hatching rates, thereby underestimating the viability of taxa (Schwinghamer 1981). Furthermore, different methods may produce an array of morphological damages on separated organisms, limiting an accurate morphological identification. In addition, many scientists have recently started to use DNA barcoding (i.e. molecular identification) for species identification instead of traditional morphological identification, but no study to date has estimated the effect of a separating solution on the success of DNA extraction or PCR amplification. As both separation methods require up to $2 \mathrm{~h}$ for the processing of 4 sample replicates (E. Briski \& S. Bailey pers. obs.), the time and resources necessary to process samples may decrease dramatically if only a single method can fully characterize each sample.

Both methods rely on differences in density between inorganic and organic matter to effect separation (de Jonge \& Bouwman 1977, Hairston \& Van Brunt 1994, Hairston et al. 1995, Burgess 2001). Sediments are largely comprised of inorganic minerals having specific gravities ranging from approximately 2.5 to $2.8 \mathrm{~g} \mathrm{~cm}^{-3}$ (Weast 1965), while the organic meiofauna and dormant stages are much less dense, having an approximate specific gravity of $1.15 \mathrm{~g} \mathrm{~cm}^{-3}$ (Price et al. 1977). Separation of organic matter occurs when the density of the solution is higher than the density of the organic matter (organics float) but lower than the density of minerals (minerals sink; Burgess 2001). The specific gravity of most commercially available sols ranges from 1.2 to $1.4 \mathrm{~g} \mathrm{~cm}^{-3}$ (Burgess 2001), while that of a 1:1 mixture (weight: volume) of sucrose and water is $1.22 \mathrm{~g} \mathrm{~cm}^{-3}$, making either option effective solutions for separation. However, Schwinghamer (1981) reported that Ludox kills foraminiferans and did not recommend Ludox for separation of 'soft' meiofauna and living specimens.
Here we conducted a comparative assessment of the 2 flotation methods by separating dormant stages of invertebrates from 160 ballast sediments and examining resulting abundance counts, hatching results, DNA extraction and PCR amplification. We tested the following hypotheses: (1) colloidal silica sol Ludox HS 40 separates more invertebrate dormant stages from sediment than does sugar flotation; (2) dormant stages separated by sugar flotation have higher hatching rates than those separated by Ludox HS 40; and (3) DNA extraction and PCR amplification from dormant stages separated by colloidal silica sol Ludox HS 40 and sugar flotation are of the same quality. Consequently, we tested the hypothesis that only 1 separation method is sufficient for comprehensive ecological studies of dormant stages in sediment.

\section{MATERIALS AND METHODS}

\section{Sample collection}

As part of a larger study conducted between June 2007 and August 2009 (Briski et al. 2011a), we sampled ballast sediments opportunistically from 160 ships arriving to the Great Lakes and to Pacific and Atlantic ports in Canada. Approximately $6 \mathrm{~kg}$ of sediment, ranging in composition from sand to silty clay, were collected from each ship. Each sediment sample was homogenized and stored in the dark at $4^{\circ} \mathrm{C}$ for at least $4 \mathrm{wk}$ to break diapause of dormant stages before experiments commenced (Grice \& Marcus 1981, Schwartz \& Hebert 1987, Dahms 1995). Every sediment sample was simultaneously processed by Ludox HS 40 and sugar flotation to avoid an influence of storage length (Briski et al. 2011b). Additionally, financial costs associated with Ludox HS 40 versus sugar flotation were estimated.

\section{Dormant stage separation using Ludox HS 40}

Four $40 \mathrm{~g}$ subsamples were randomly separated from each of 160 samples and sieved through a $45 \mu \mathrm{m}$ sieve, and the retained material was then washed into 2 to 4 centrifuge tubes $(50 \mathrm{ml})$ using Ludox HS 40 with a specific gravity of $1.31 \mathrm{~g} \mathrm{~cm}^{-3}$. The number of centrifuge tubes used depended on the amount of retained material. Approximately $30 \mathrm{ml}$ of Ludox were added into every sample tube, resulting in a total sample volume of approximately 40 to $45 \mathrm{ml}$. The tubes were mixed and then centrifuged at approximately $7.7 \mathrm{~m} \mathrm{~s}^{-2}$ (5 $\left.\mathrm{min}\right)$. The supernatant was then de- 
canted and rinsed with double-distilled $\mathrm{H}_{2} \mathrm{O}\left(\mathrm{ddH}_{2} \mathrm{O}\right)$ through a $45 \mu \mathrm{m}$ mesh and placed into Petri dishes containing approximately $15 \mathrm{ml}$ of $\mathrm{ddH}_{2} \mathrm{O}$. Under a dissecting microscope, dormant stages were counted and grouped taxonomically (i.e. Rotifera, Bryozoa, Branchiopoda and Copepoda). Every dormant stage counted was transferred into a $1.5 \mathrm{ml}$ reaction tube for DNA extraction. An additional 12 subsamples (40 g each) were processed for hatching experiments when subsamples contained at least 1 dormant stage. The subsamples processed for hatching experiments were rinsed with sterile synthetic pond water (0 ppt; Hebert $\&$ Crease 1980) or a sterile seawater medium.

The Ludox HS 40 sol was reused up to 3 times until its specific gravity was lowered due to absorption of water contained in samples. The density of the solution was monitored with a hydrometer and sieved through $20 \mu \mathrm{m}$ mesh before reuse.

\section{Dormant stage separation using sugar flotation}

Four $40 \mathrm{~g}$ subsamples of sediment were randomly separated from each of 160 samples and sieved through a $45 \mu \mathrm{m}$ sieve; the retained material was washed into centrifuge tubes using a 1:1 mixture (weight:volume) of sucrose and water and centrifuged at approximately $7.7 \mathrm{~m} \mathrm{~s}^{-2}$ (5 min). The supernatant was decanted and rinsed with $\mathrm{ddH}_{2} \mathrm{O}$ through a $45 \mu \mathrm{m}$ mesh and placed into Petri dishes containing approximately $15 \mathrm{ml}$ of $\mathrm{ddH}_{2} \mathrm{O}$. As with Ludox HS 40, dormant stages were counted under a dissecting microscope and transferred into $1.5 \mathrm{ml}$ reaction tubes for DNA extraction. An additional 12 subsamples (40 g) were processed for hatching experiments, when subsamples contained at least 1 dormant stage. The subsamples processed for hatching experiments were rinsed with sterile synthetic pond water or a sterile seawater medium.

\section{Hatching experiments of separated dormant stages}

Dormant stages isolated from sediment using Ludox HS 40 and sugar flotation were immediately placed into vials containing $15 \mathrm{ml}$ of sterile synthetic pond water or $15 \mathrm{ml}$ of a sterile seawater medium. The seawater medium was prepared from natural seawater collected from a vessel transiting the Great Lakes loaded with ocean ballast water, filtered through a $2.5 \mu \mathrm{m}$ Whatman paper filter, and diluted to 15 and $30 \mathrm{ppt}$ with sterile, synthetic pond water (0 ppt). Four replicates of $40 \mathrm{~g}$ subsamples were placed into each of the 3 media treatments $(0,15$, $30 \mathrm{ppt}$ ) under a light:dark cycle of $16: 8 \mathrm{~h}$, at $20^{\circ} \mathrm{C}$. Three different salinities were used in an attempt to match unknown species to a fresh-, brackish- or saltwater habitat, thereby maximizing hatching success. Controls containing only synthetic pond water were kept in each treatment group to monitor for introduction of organisms from the environment. Vials were checked for emergence every $24 \mathrm{~h}$ for the first $10 \mathrm{~d}$ and every $48 \mathrm{~h}$ for a subsequent $10 \mathrm{~d}$ (Bailey et al. 2005), with media renewed every $5 \mathrm{~d}$.

\section{DNA extractions, PCRs and gel electrolyses}

Separated dormant stages were rinsed thoroughly in $\mathrm{ddH}_{2} \mathrm{O}$ several times to remove external debris before DNA extraction (Briski et al. 2011c). DNA was extracted from dormant stages using the HotSHOT method (Montero-Pau et al. 2008). Individual dormant stages were placed into $1.5 \mathrm{ml}$ reaction tubes containing $15 \mu \mathrm{l}$ of alkaline lysis buffer $(\mathrm{NaOH}$ $25 \mathrm{mM}$, disodium EDTA $0.2 \mathrm{mM}, \mathrm{pH}$ 8.0). Once in the buffer, the dormant stage was crushed against the side of the tube using a sterile needle under a dissecting microscope. Samples were incubated at $95^{\circ} \mathrm{C}$ for $30 \mathrm{~min}$ and placed on ice for $3 \mathrm{~min}$. Finally, $15 \mu \mathrm{l}$ of neutralizing buffer (Tris- $\mathrm{HCl} 40$ mM, pH 5.0) were added to each tube. DNA was quantified using a Nanovue spectrophotometer (GE Healthcare), and fragments of the mitochondrial cytochrome $c$ oxidase subunit I (COI) and 16S rDNA (16S) were amplified from each dormant stage to confirm successful DNA extraction. Amplification was done using the universal COI primers LCO1490 and HCO2190 (Folmer et al. 1994) and universal $16 \mathrm{~S}$ primers $\mathrm{S} 1$ and $\mathrm{S} 2$ (Palumbi 1996). PCR reactions were performed in a total volume of $25 \mu \mathrm{l}$ using $5 \mu \mathrm{l}$ of DNA extract, $1 \times$ PCR buffer, $0.13 \mathrm{mM}$ trehalose, $0.1 \mu \mathrm{M}$ of each primer, $2.5 \mathrm{mM} \mathrm{MgCl}_{2}, 0.14 \mathrm{mM}$ dNTPs, and $0.4 \mathrm{U}$ Top Taq DNA polymerase (Qiagen). The thermal profile consisted of a $1 \mathrm{~min}$ initial cycle at $94^{\circ} \mathrm{C}$, followed by 5 cycles of $94^{\circ} \mathrm{C}(40 \mathrm{~s}), 45^{\circ} \mathrm{C}(40 \mathrm{~s})$, and $72^{\circ} \mathrm{C}$ $(1 \mathrm{~min}), 35$ cycles of $94^{\circ} \mathrm{C}(40 \mathrm{~s}), 50^{\circ} \mathrm{C}(40 \mathrm{~s})$, and $72^{\circ} \mathrm{C}$ (1 min), and a final extension of $72^{\circ} \mathrm{C}$ for $5 \mathrm{~min}$. PCR products were verified on $1 \%$ agarose gel. DNA extraction was assumed successful if the results of PCR amplification resulted in at least 1 amplified marker (COI or 16S). Even though not for the purpose of this study, a maximum of 15 dormant stages per different morphological group from every sample were sequenced for species identification (results shown in Briski et al. 2011a,b,c). 

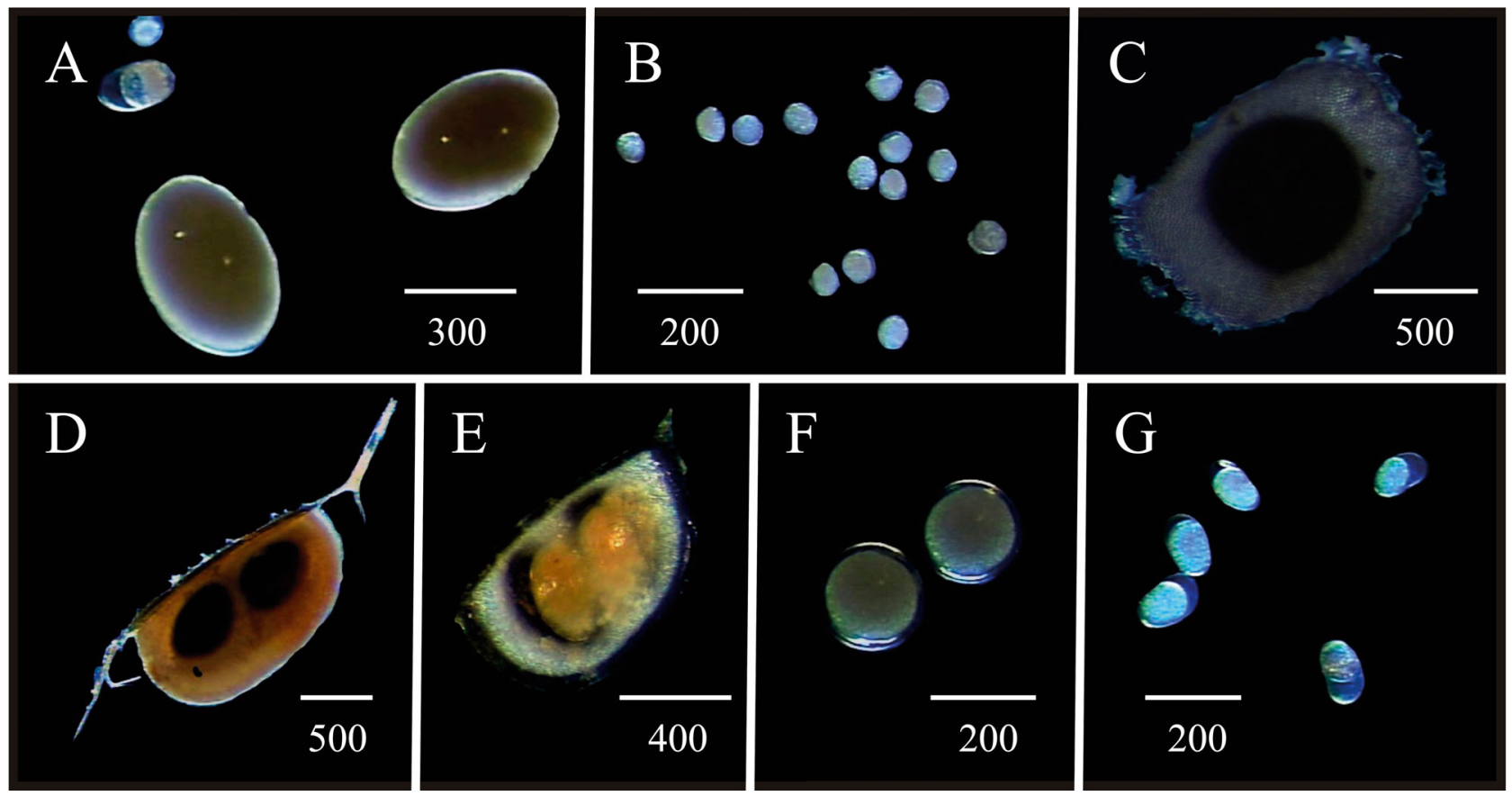

Fig. 1. Dormant stage morphotypes. (A) Various dormant stages; (B) Copepoda; (C) Bryozoa; (D) Daphnia magna (Branchiopoda); (E) D. mendotae (Branchiopoda); (F) Podon intermedius (Branchiopoda); (G) Brachionus calyciflorus (Rotifera). Scale bars are in $\mu \mathrm{m}$

\section{Statistical analyses}

All data were log transformed to meet assumptions of parametric tests. Variation in dormant stage counts, hatching experiments, and PCR amplifications between the Ludox HS 40 and sugar flotation methods were compared using multivariate ANOVA (MANOVA), where taxa (Rotifera, Bryozoa, Branchiopoda, Copepoda) were dependent variables and method (Ludox HS 40, sugar flotation) was the independent variable. Three separate MANOVAs were performed assessing dormant stage counts, hatching rates and success of PCR amplifications. Significance levels for statistical comparisons were adjusted for multiple pairwise comparisons by Bonferroni-type correction with a family-wise error rate of 0.05 .

\section{RESULTS}

Both methods separated the same types of dormant stages (i.e. Rotifera, Bryozoa, Branchiopoda, Copepoda; Fig. 1). Although the average abundance of dormant stages of all taxonomic groups counted after separation from sediment using Ludox HS 40 was slightly higher than that counted after sugar flotation, the differences were not statistically significant (p > 0.05; Tables $1 \& 2$ ). Average abundance of different taxonomic groups ranged from 2.29 to 67.69 and from 2.13 to 66.52 dormant stages per $40 \mathrm{~g}$ of sediment after Ludox HS 40 and sugar flotation, respectively (Table 1). Bryozoa had the lowest abundance, followed by Rotifera and Branchiopoda, while average abundance of Copepoda was an order of magnitude higher than that of the other 3 taxonomic groups (Table 1).

Contrary to the counting results, hatching rates of dormant stages separated from sediment using Ludox HS 40 were slightly lower than those separated using sugar flotation, although again, differences were not statistically significant for any taxon ( $p>0.05$; Tables $1 \& 2$ ). The average hatching rate of dormant stages after separation from sediment using Ludox HS 40 were 51, 18 and 52\% for Rotifera, Branchiopoda and Copepoda, respectively, and 53, 21 and $53 \%$, respectively, following separation using sugar flotation (Table 1). Bryozoa did not hatch from dormant stages separated using either method (Table 1).

Similar to the counting and hatching results, we did not find statistical differences in PCR amplification success for any taxonomic group separated by the 2 methods ( $p>0.05_{i}$, Tables $\left.1 \& 2\right)$. The average proportion of successful PCR amplifications from dormant stages separated from sediment using Ludox 
Table 1. Mean $( \pm \mathrm{SE})$ number of dormant stages separated from sediment, hatched in hatching experiments, and from which DNA was amplified, after separation using the colloidal silica sol Ludox HS 40 and sugar flotation methods

\begin{tabular}{|lcccccc|}
\hline \multirow{2}{*}{ Taxon } & \multicolumn{2}{c}{ Dormant stage counts } & \multicolumn{2}{c}{ Hatching experiments } & \multicolumn{2}{c|}{ PCR amplifications } \\
& Ludox HS 40 & Sugar flotation & Ludox HS 40 & Sugar flotation & Ludox HS 40 & Sugar flotation \\
\hline Rotifera & $5.06( \pm 0.94)$ & $4.86( \pm 0.89)$ & $2.59( \pm 1.40)$ & $2.60( \pm 1.40)$ & $2.35( \pm 0.70)$ & $2.40( \pm 0.71)$ \\
Bryozoa & $2.29( \pm 0.43)$ & $2.13( \pm 0.40)$ & 0 & 0 & $1.05( \pm 0.16)$ & $1.07( \pm 0.17)$ \\
Branchiopoda & $10.26( \pm 2.35)$ & $9.73( \pm 2.17)$ & $1.89( \pm 0.59)$ & $2.07( \pm 0.52)$ & $4.57( \pm 1.05)$ & $4.07( \pm 0.96)$ \\
Copepoda & $67.69( \pm 15.76)$ & $66.52( \pm 15.85)$ & $35.15( \pm 23.44)$ & $35.36( \pm 23.51)$ & $21.66( \pm 5.25)$ & $23.87( \pm 5.72)$ \\
Total & $72.37( \pm 14.60)$ & $70.75( \pm 14.66)$ & $27.61( \pm 17.85)$ & $27.71( \pm 17.90)$ & $23.92( \pm 4.93)$ & $25.08( \pm 5.20)$ \\
\hline
\end{tabular}

Table 2. Multivariate ANOVA addressing the effect of separation method (colloidal silica sol Ludox HS 40 and sugar flotation) on dormant stage counts, hatching experiments, and PCR amplifications for diversified taxa. na: not applicable

\begin{tabular}{|c|c|c|c|c|c|c|c|c|c|c|c|c|}
\hline \multirow[t]{2}{*}{ Dependent variable } & \multicolumn{4}{|c|}{ Dormant stage counts } & \multicolumn{4}{|c|}{ Hatching experiments } & \multicolumn{4}{|c|}{ PCR amplifications } \\
\hline & Value & $\mathrm{df}$ & $F$ & $\mathrm{p}$ & Value & $\mathrm{df}$ & $F$ & $\mathrm{p}$ & Value & $\mathrm{df}$ & $F$ & $\mathrm{p}$ \\
\hline \multicolumn{13}{|l|}{ Univariate $F$-tests } \\
\hline Rotifera & & 1 & 0.043 & 0.837 & & 1 & 1.000 & 0.423 & & 1 & 0.215 & 0.647 \\
\hline Bryozoa & & 1 & 0.031 & 0.860 & & na & na & na & & 1 & 0.141 & 0.711 \\
\hline Branchiopoda & & 1 & 0.123 & 0.728 & & 1 & 1.000 & 0.423 & & 1 & 0.045 & 0.834 \\
\hline Copepoda & & 1 & 0.091 & 0.764 & & 1 & 0.151 & 0.735 & & 1 & 0.070 & 0.793 \\
\hline \multicolumn{13}{|l|}{ Multivariate test } \\
\hline Wilks' lambda & 0.987 & 4 & 0.113 & 0.977 & 0.039 & 3 & 12.346 & 0.197 & 0.989 & 4 & 0.055 & 0.994 \\
\hline
\end{tabular}

HS 40 was 46, 46, 45 and $32 \%$ for Rotifera, Bryozoa, Branchiopoda and Copepoda, respectively, and using sugar flotation, $49,50,42$ and $36 \%$, respectively (Table 1).

The initial purchase cost of Ludox HS 40 (CAD\$39.70 $\mathrm{l}^{-1}$ ) was 20 times higher than the cost of sucrose $\left(\mathrm{CAD} \$ 0.65 \mathrm{l}^{-1}\right)$, although the Ludox HS 40 was reused 3 times, lowering the cost to CAD\$13.23 $\mathrm{l}^{-1}$. Furthermore, processing time was identical for both methods at $8 \mathrm{~h}$ per 16 subsamples of each sediment, which resulted in $1280 \mathrm{~h}$ for 160 samples per method. As minimum hourly wage in Canada is above CAD $\$ 10.00$, the costs of labour for processing of 160 samples by only 1 method were above CAD\$12800 CAD.

\section{DISCUSSION}

Our study showed that both methods, the colloidal silica sol Ludox HS 40 and sugar flotation, are equally suitable for separation of dormant stages from sediment to assess abundance and viability, as well as to conduct genetic studies. As both separation methods rely on differences in density between minerals, separation solution and organic matter to effect separation (Hairston \& Van Brunt 1994, Hairston et al. 1995, Burgess 2001), the efficacy of dormant stage separation may be maximized by continually confirming the specific gravity of the colloidal silica sol or sucrose solution. Excessive reuse of the colloidal silica sol Ludox HS 40 or inaccurate measurements of sugar and water in the sucrose mixture may lead to lower specific gravity with consequent dispersion of meiofauna and dormant stages throughout the column of the separation solution instead of rising to the upper surface. The specific gravity of the separation solutions can be easily increased to overcome this problem by adding concentrated Ludox HS 40 or additional sugar.

Contrary to 'soft' meiofauna, dormant stages of invertebrates are protected by a layered shell resistant to ruptures when squeezed or prodded by a sharp object (Lavens \& Sorgeloos 1996, Marcus 1996, Dharani \& Altaff 2004). While many active marine invertebrates and algae may be damaged by exposure to the highly saturated solutions used to separate biota from sediment (Price \& Reardon 1978, Schwinghamer 1981), most dormant stages can withstand very harsh environmental conditions such as desiccation, large fluctuations in salinity and anoxic conditions (Lavens \& Sorgeloos 1996, Cáceres 1997, Bailey et al. 2004, Schröder 2005). As a result, osmotic stress 
or toxicity induced by suspension in a separation solution may not damage or reduce viability of the embryo inside the shell (Lavens \& Sorgeloos 1996). We suggest that the hatching results in our study, ranging from 0 to $53 \%$, were not influenced by the separation solution, but were an effect of dormancy itself. The physiology of dormant stages is very complex, with hatching success depending on the presence of appropriate cues to terminate dormancy, energy content of the dormant stage, and hatching conditions, with low hatching rates being a common result. Hatching results reported in the literature range from 0 to $40 \%$ (Schwartz \& Hebert 1987, Lavens \& Sorgeloos 1996, Hairston et al. 1999, Bailey et al. 2003, Simm \& Ojaveer 2006).

Correct identification of species is essential for ecological studies, and a recent study has demonstrated that DNA barcoding identifies nearly twice the number of species from invertebrate dormant stages as does traditional morphological taxonomy (Briski et al. 2011c). We suggest that the DNA extraction and PCR amplification results in our study, ranging from 0 to $50 \%$, were not influenced by the separation solution. Successful molecular identification may be limited if extracted DNA is degraded (Briski et al. 2011c) or if inhibitors of DNA extraction and/or PCR amplification, such as sediment, iron, bacterial cells, or other organic compounds, are present (Wilson 1997). Such inhibitors are often found in ballast tanks. Furthermore many dormant stages were visibly degraded or damaged.

Our study demonstrated that there is no need to apply both the colloidal silica sol Ludox HS 40 and sugar flotation methods on the same sediment sample to accurately estimate density and viability of invertebrate dormant stages in sediment or to conduct genetic studies on dormant stages. Researchers can reduce time and costs by using only a single method. Although our study compared the 2 methods using ships' ballast sediment, the results should be equally applicable for sediment samples collected in natural habitats, facilitating early detection of new invading species and determining the invasion history of species in sediment cores. In addition to invasion ecology, our results are equally applicable to other ecological studies such as taxonomy, ecological biogeography, paleolimnology, nature conservation, and evolutionary, community and population ecology.

Acknowledgements. We thank the Shipping Federation of Canada and the multiple shipping companies that facilitated access to vessels, as well as our ballast sampling teams: C. van Overdijk, A. M. Weise, O. Casas-Monroy, N. Simard,
J. Y. Couture, M. Huot, C. Owens, O. Lacasse, K. MacIntosh, B. Piercey, D. Humphrey, S. Ballard, M. Whitehead, P. Lolic, G. Leung, P. Luk, C. McKindsey and C. Levings. We are grateful to R. Tedla, S. Ross and H. Coker for laboratory support and to M. Cristescu for making her laboratory resources available. This research was supported by NSERC's Canadian Aquatic Invasive Species Network, Transport Canada, Fisheries and Oceans Canada (DFO), NSERC Discovery Grants (to S.A.B. and H.J.M.), and a DFO Invasive Species Research Chair (to H.J.M.).

\section{LITERATURE CITED}

Arnott SE, Yan ND, Magnuson JJ, Frost TM (1999) Interannual variability and species turnover of crustacean zooplankton in Shield lakes. Can J Fish Aquat Sci 56: 162-172

Bailey SA, Duggan IC, van Overdijk CDA, Jenkins PT, MacIsaac HJ (2003) Viability of invertebrate diapausing stages collected from residual ballast sediment of transoceanic vessels. Limnol Oceanogr 48:1701-1710

> Bailey SA, Duggan IC, van Overdijk CDA, Johengen $\mathrm{TH}$, Reid DF, MacIsaac HJ (2004) Salinity tolerance of diapausing eggs of freshwater zooplankton. Freshw Biol 49: 286-295

Bailey SA, Duggan IC, Jenkins PT, MacIsaac HJ (2005) Invertebrate resting stages in residual ballast sediment of transoceanic ships. Can J Fish Aquat Sci 62:1090-1103

$>$ Brendonck L, De Meester L (2003) Egg banks in freshwater zooplankton: evolutionary and ecological archive in the sediment. Hydrobiologia 491:65-84

Briski E, Bailey SA, Cristescu ME, MacIsaac HJ (2010) Efficacy of 'saltwater flushing' in protecting the Great Lakes from biological invasions by invertebrate eggs in ships' ballast sediment. Freshw Biol 55:2414-2424

Briski E, Bailey SA, MacIsaac HJ (2011a) Invertebrates and their dormant eggs transported in ballast sediments of ships arriving to the Canadian coasts and the Laurentian Great Lakes. Limnol Oceanogr 56:1929-1939

- Briski E, Ghabooli S, Bailey SA, MacIsaac HJ (2011b) Assessing invasion risk across taxa and habitats: life stage as a determinant of invasion success. Divers Distrib 17:593-602

> Briski E, Cristescu ME, Bailey SA, MacIsaac HJ (2011c) Use of DNA barcoding to detect invertebrate invasive species from diapausing eggs. Biol Invasions 13:1325-1340

> Burgess R (2001) An improved protocol for separating meiofauna from sediments using colloidal silica sols. Mar Ecol Prog Ser 214:161-165

> Cáceres CE (1997) Dormancy in invertebrates. Invertebr Biol 116:371-383

> Dahms HU (1995) Dormancy in the Copepoda-an overview. Hydrobiologia 306:199-211

> de Jonge VN, Bouwman LA (1977) A simple density separation technique for quantitative isolation of meiobenthos using the colloidal silica Ludox-TM. Mar Biol 42:143-148

Dharani G, Altaff K (2004) Ultra structure of subitaneous and diapausing eggs of planktonic copepod Sinodiaptomus (Rhinediaptomus) indicus. Curr Sci 87:109-112

> Duggan IC, van Overdijk CDA, Bailey SA, Jenkins PT, Limen H, MacIsaac HJ (2005) Invertebrates associated with residual ballast water and sediments of cargo-carrying ships entering the Great Lakes. Can J Fish Aquat Sci 62:2463-2474 
Duggan IC, Bailey SA, van Overdijk CDA, MacIsaac HJ (2006) Invasion risk of active and diapausing invertebrates from residual ballast in ships entering Chesapeake Bay. Mar Ecol Prog Ser 324:57-66

Folmer O, Black M, Hoeh W, Lutz R, Vrijenhoek R (1994) DNA primers for amplification of mitochondrial cytochrome $c$ oxidase subunit I from diverse metazoan invertebrates. Mol Mar Biol Biotechnol 3:294-299

Folt CL, Burns CW (1999) Biological drivers of zooplankton patchiness. Trends Ecol Evol 14:300-305

Grice GD, Marcus NH (1981) Dormant eggs of marine copepods. Oceanogr Mar Biol Annu Rev 19:125-140

Hairston NG, Van Brunt RA (1994) Diapause dynamics of two diaptomid copepod species in a large lake. Hydrobiologia 292-293:209-218

Hairston NG, Van Brunt RA, Kearns CM, Ergstrom DR (1995) Age and survivorship of diapausing eggs in a sediment egg bank. Ecology 76:1706-1711

Hairston NG, Perry LJ, Bohonak AJ, Fellows MQ, Kearns CM (1999) Population biology of a failed invasion: paleolimnology of Daphnia exilis in upstate New York. Limnol Oceanogr 44:477-486

Hebert PDN, Crease TJ (1980) Clonal co-existence in Daphnia pulex (Leydig): another planktonic paradox. Science 207:1363-1365

Jeppesen E, Jensen JP, Lauridsen TL, Amsinck SL, Christoffersen K, Søndergaard M, Mitchell SF (2003) Sub-fossils of cladocerans in the surface sediment of 135 lakes as proxies for community structure of zooplankton, fish abundance and lake temperature. Hydrobiologia 491:321-330

Lavens P, Sorgeloos P (1996) Manual on the production and use of live food for aquaculture. Fish Tech Pap. FAO, Rome

Marcus NH (1990) Calanoid copepod, cladoceran, and rotifer eggs in sea-bottom sediments of northern Californian coastal waters: identification, occurrence and hatching. Mar Biol 105:413-418

Editorial responsibility: Judith Grassle,

New Brunswick, New Jersey, USA
Marcus NH (1996) Ecological and evolutionary significance of resting eggs in marine copepods: past, present, and future studies. Hydrobiologia 320:141-152

> Montero-Pau J, Gómez A, Muñoz J (2008) Application of an inexpensive and high-throughput genomic DNA extraction method for the molecular ecology of zooplanktonic diapausing eggs. Limnol Oceanogr Methods 6:218-222

Onbé T (1978) Sugar flotation method for sorting the resting eggs of marine cladocerans and copepods from sea-bottom sediment. Bull Jpn Soc Sci Fish 44:1411

Palumbi S (1996) Nucleic acids II: the polymerase chain reaction. In: Hillis D, Mable B, Moritz C (eds) Molecular systematics. Sinauer, Sunderland, MA, p 205-247

Persmark L, Banck A, Andersson S, Jansson HB (1992) Evaluation of methods for extraction of nematodes and endoparasitic fungi from soil. Nematologica 38:520-530

Price CA, Reardon EM (1978) Collection of dinoflagellates and other marine microalgae by centrifugation in density gradients of a modified silica sol. Limnol Oceanogr 23: 548-553

Price CA, Onge-Burns JM, Colton JB, Joyce JE (1977) Automatic sorting of zooplankton by isopycnic sedimentation in gradients of silica. Mar Biol 42:225-232

Schröder T (2005) Diapause in monogonont rotifers. Hydrobiologia 546:291-306

Schwartz SS, Hebert PDN (1987) Methods for the activation of the resting eggs of Daphnia. Freshw Biol 17:373-379

Schwinghamer P (1981) Extraction of living meiofauna from marine sediments by centrifugation in a silica solsorbitol mixture. Can J Fish Aquat Sci 38:476-478

Simm M, Ojaveer H (2006) Taxonomic status and reproduction dynamics of the non-indigenous Cercopagis in the Gulf of Riga (Baltic Sea). Hydrobiologia 554:147-154

Weast RC (1965) CRC handbook of chemistry and physics. Chemical Rubber Company, Cleveland, $\mathrm{OH}$

- Wilson IG (1997) Inhibition and facilitation of nucleic acid amplification. Appl Environ Microbiol 63:3741-3751

Submitted: February 18, 2013; Accepted: April 8, 2013

Proofs received from author(s): May 10, 2013 